УДК 655.3.022

( Р. С. Загородній, магістрант, Т. В. Розум, к.т.н., доцент, НТУУ «КПІ», Київ, Україна

\title{
СУЧАСНІ ТЕХНОЛОГІЇ ПЛОСКОГО ОФСЕТНОГО ДРУКУ ЗІ ЗВОЛОЖЕННЯМ
}

\section{Проаналізовано сучасний стан плоского офсетного друку зі зволоженням. Визначено основні переваги, що роблять даний напрям актуальним для подальших розробок та застосування у виробництві.}

\section{Ключові слова: плоский офсетний друк зі зволоженням; виробництво; поліграфічна продукція; ринок упаковки, сучасний стан.}

\section{Постановка проблеми}

Аналізуючи стан плоского офсетного друку, говорять про ринок поліграфічної продукції, ринок поліграфічної техніки та матеріалів. У новому тисячолітті спостерігаються значні перебудови у структурі, що зумовлено інтенсивним розвитком саме інформаційних технологій. Те, що зовсім нещодавно було прогнозами та завданнями з метою вирішення, для сьогоднішнього суспільства стало невід'ємним у побуті та на виробництві. Якщо актуальними темами минулого десятиліття вважались автоматизовані системи проходження замовлення workflow, розглядались переваги та проводились порівняння технології ctp та ctf, то сьогодні головним питанням $€$ проблеми сталого розвитку на рівні окремих підприємств (економічні) та на глобальному рівні (екологічні). Саме в аспекті сталого розвитку актуальним є увиразнення сучасного стану та можливостей, адже підсумки попереднього етапу $є$ вагомою складовою у формуванні вектора майбутніх досліджень та розробок [1].

\section{Аналіз попередніх}

\section{досліджень}

Сьогодні відомими є роботи Величко О. М., Золотухіної К. І., Зоренко О. В., Розум Т. В., які розглянули сучасний стан технологій друкування в Україні, роботи Кривошея В., який займався вивченням, цільової для офсетного способу друку, індустрії виготовлення упаковки [2, 3]. Дуже корисними при аналізі сучасного стану стали роботи львівських колег: Мельникова О. М. та Шаблія І. В. Крім того не менш важливими є публікації у спеціалізованих періодичних виданнях. Такі роботи Золотухіної К. І., Кушлика Б. Р., наукові праці Зоренка Я. В., Скиби В. М., та інших $€$ комплексними в межах своєї тематики і досить детально розкривають сутність окремих

(C) $2016 \mathrm{p}$. 


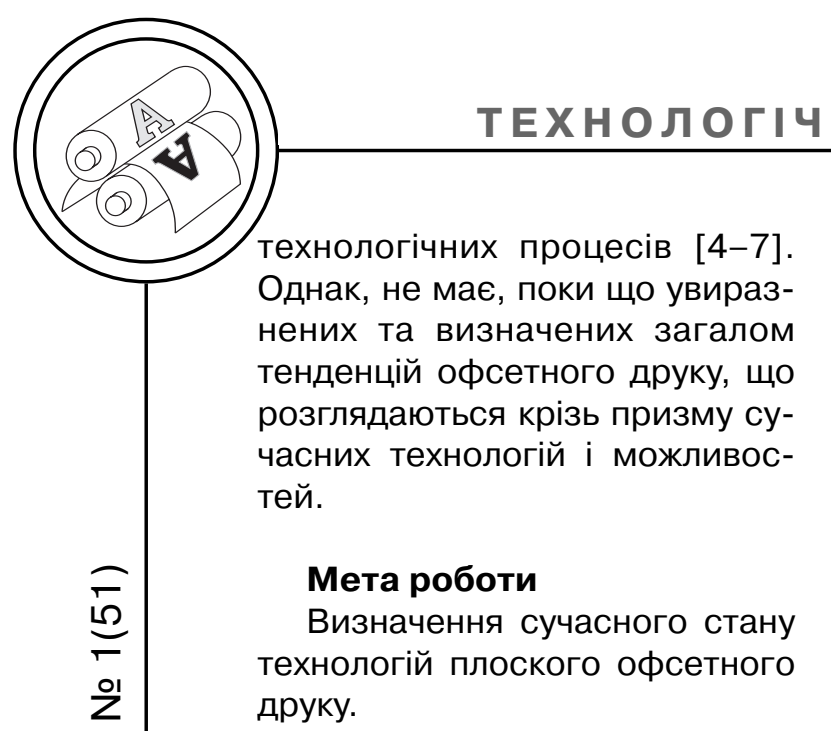

\section{Результати проведених} досліджень

На сьогодні переважна частина ринку поліграфічної продукції залежить від попиту на комплементарні товари. Мова йде про ринок упаковки, який невпинно зростає на 4-5\% в рік, на фоні зовсім незначного росту загального ринку поліграфічної продукції. За свідченнями [3], 50 \% ринку займає гнучке паковання, а картонна упаковка на світовому ринку складає всього $10 \%$. Це пояснюється тим, що полімерна упаковка має ряд технологічних переваг: менші складність та витрати при виготовленні і утилізації $[3,8]$.

Статистичні дані ринку поліграфічного обладнання за останні два роки показують наявність та незначний спад попиту на друкарські офсетні машини (надалі - ДМ) в країнах ближнього зарубіжжя та значно більший стабільний попит на пристрої СТР, що наочно ілюструє процес адаптації друкарень до ринку з малими тиражами та великою кількістю замовлень. Навіть друкуючи малоформатними друкарськими машинами час друку та час на виведення комплекту друкарських форм за таких умов може збігатись. В результаті маємо підвищення попиту на СТР, та підтверджений статистичними даними в двічі більший попит на цифрові друкарські машини, хоча підприємці по усьому світу демонструють прибутковість офсету тиражем від 150 відбитків [9].

Конкуренція таких виробничих гігантів як KBA, manroland, Heidelberg дозволила вивести на максимум швидкість листових ДМ подвійного формату (18000 відб./год.), зробити стандартом автоматизоване обладнання, автоматичний контроль та регулювання параметрами друку, універсальність складових частин ДМ для різних матеріалів, що задруковуються, максимально опустити норму витрат на приладку. Усе це робить офсетний спосіб друку гнучким у сучасних умовах, не зважаючи на те, що друкарська машина - це важка механіка 3 великою кількістю контрольованих параметрів [9, 10].

Розглядаючи інші варіанти досягнення гнучкості, виробники пропонують встановлювати спеціалізовані багатосекційні ДМ, що дозволяють здійснити максимальну кількість операцій в лінію без відчутного зменшення швидкості друку. Поки друкується перший тираж у чотири фарби CMYK, в інші чотири секції вже можна завантажувати друкарські форми, та налаштовувати для друку наступного тиражу, таким чином перейти 3 одного тиражу на інший не зупиняючи ДМ [9-11].

Останні тенденції, щодо автоматизації офсетного друку, 
скорочення виробничого циклу, підвищення швидкості та економічності виготовлення продукції втілюються не лише у створенні нового сучасного обладнання, а й у комп'ютеризації старої техніки, вмонтовуючи сучасні засоби контролю та керування. В якості прикладу можна навести системи DCOS та Quad Tech, що дозволяють автоматизувати процес приведення, вирівнювання полотна та «попадання в колір» газетних ДМ. Як наслідок це дозволяє зробити кольори та параметри друкування більш рівномірними у всьому тиражі, знизити кількість макулатури, що витрачається на приведення [12, 13].

Технологія web-to-print $€$ втіленням сучасних інформаційних технологій поліграфічного виробництва. Розрізняють два способи застосування: використання web-to-print, як засіб отримання та підготовки замовлень для однієї конкретної друкарні чи мережі друкарень, або формування бізнесу як інформаційної платформи, що надає послуги великій кількості друкарень та, відповідно, клієнтів. Яскравим прикладом утілення такої технології $\epsilon$ сервіс vizitka.com, що завоювавши український ринок цифровими друкарськими машинами, активно поширюється в країнах ближнього зарубіжжя. Важливо, що даний сервіс не лише автоматизував додрукарські процеси та процес оформлення замовлень, а утворює собою цілу систему, що включає в себе велику кількість спеціалістів 3 додрукарської підготовки та друкарень, які власне і виконують замовлення та обираються залежно від географічного розташування, об'єму замовлення, завантаженості виробництва. Подібні глобалізовані проекти є досить актуальними за умов подорожчання пального та тенденцій до економії природних ресурсів, дозволяє залучити велику кількість спеціалізованих підприємств, що повинно позитивно вплинути на вітчизняну економіку [14, 15].

Загалом ідея поділу тиражів на територіальні сектори зародилася досить давно, вона дозволяє значно розширити границі поширення видавничої продукції без додаткових витрат. Оскільки видавництво продаватиме продукцію не кінцевим споживачам, а друкарням чи дилерам у вигляді ліцензії виробництво на продаж. А на місцях один і той же вид продукції може відтворюватись у визначеній кількості та способами друку залежно від кількості зацікавлених споживачів [15].

На ринку досі представлені технології виведення аналогових друкарських форм: CtF (з комп'ютера на фотоформу) та СТсP (з комп'ютера на аналогову друкарську форму). CtF застосовується для виготовлення друкарських форм вибіркового лакування УФ-лаками. Основною перевагою технології СТсР $€$ дешевизна друкарських пластин та можливість застосування вивідного пристрою планшетного типу для виготовлення флексографічних друкарських форм чи іншої суміжної продукції. В країнах ближнього зарубіжжя технологія СТсР набу- 


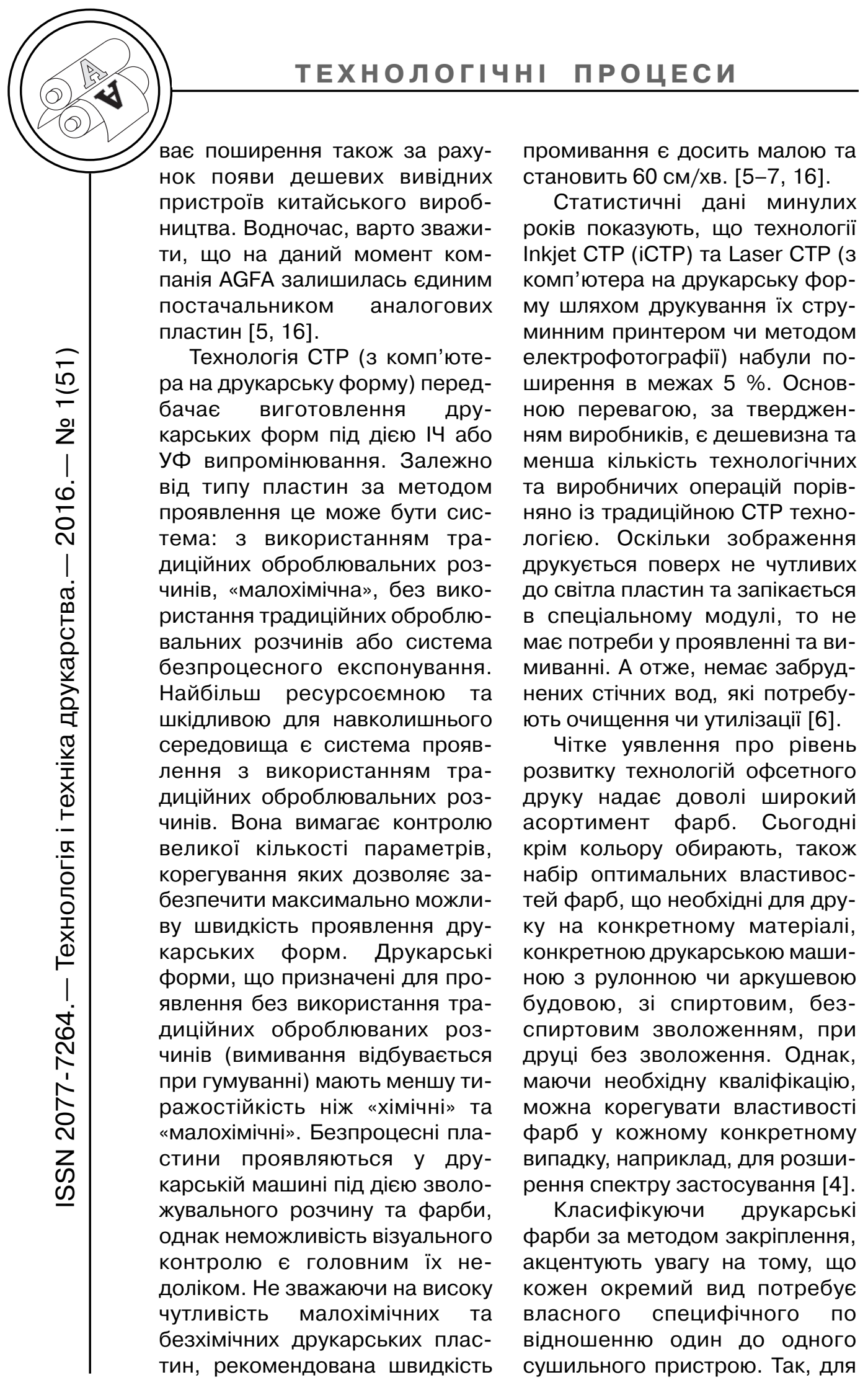


рулонних машин, де використовуються швидкосохнучі фарби 3 механізмом закріплення за рахунок випаровування розчинника використовують газові сушки, для УФ-фарб - відносно нові HR-UV, LED-UV та H-UV сушки, які, як відомо, мають значно вужчий спектр випромінювання ніж звичайні УФлампи, що дозволило підвищити швидкість полімеризації фарб. Електронно-променева сушка каталізує полімеризацію за рахунок дії електронного пучка. Крім того, ніхто не відміняв, обдування повітрям та ІЧ-сушарку, яка пришвидшує випаровування розчинника, але водночас підвищує температуру відбитків. Гібридні фарби говорять самі за себе, мають пришвидшений механізм сушки за рахунок закріплення під впливом кількох факторів, наділені перевагами УФ-фарб та позбавлені недоліків традиційних фарб. Так, наприклад, лакування УФлаком поверх гібридних фарб не потребує попереднього накладання праймера, для газетного друку УФ-фарби вдається заполімеризувати зупинивши їх всотування у волокна паперу тим самим підвищивши яскравість та контраст $[4,17,18]$.

На жаль, давно відомі швидкосохнучі фарби УФ-твердіння та фарби, що закріплюються під дією електронно-променевої сушки, як і раніше містять шкідливі компоненти, що накладає ряд обмежень на їх застосування. Відносно нові УФ-фарби зі зниженою міграцією, пройшли перевірку у країнах Європи і зараз широко застосовуються при виготовленні упаковки та питання безпечності такої продукції для дітей, наприклад, залишається відкритим [19].

Загалом, розглядаючи офсетний спосіб друку як систему різноманітних технологій, можна значно розширити уявлення про межі його застосування, насамперед присвоєнням долі ринку на межах поділу умовних сегментів за рахунок вищої рентабельності чи інших переваг. Так при друці на тонких полімерних плівках, конкуренцію вузькорулонним флексографічним машинам складає малоформатний офсетний друк, за рахунок вартості друкарських форм, перевагах у швидкості друку, оскільки на одному фарбовідбитку можна розмістити більше інформації, отримати беззаперечну якість. Крім того в разі великої необхідності, ДМ офсетного друку можна дооснастити флексографічними секціями, для отримання визначеного ефекту [20, 21].

При друці збірних тиражів застосовують прийоми задруковування паперу різного розміру з одного комплекту ДФ, тим самим варіюючи тиражність продукції, що попадає за межі меншого аркуша.

На основі аналітичного огляду літературних джерел, монографій, наукової та фахової періодики загальною кількістю понад 100 було розроблено алгоритм процесу плоского офсетного друку зі зволоженням, що налічує 274 операції та 55 розгалужень процесу. Для прикладу на рис. наведено частину алгоритму, що містить операції з підготовки зволожувального розчину. 


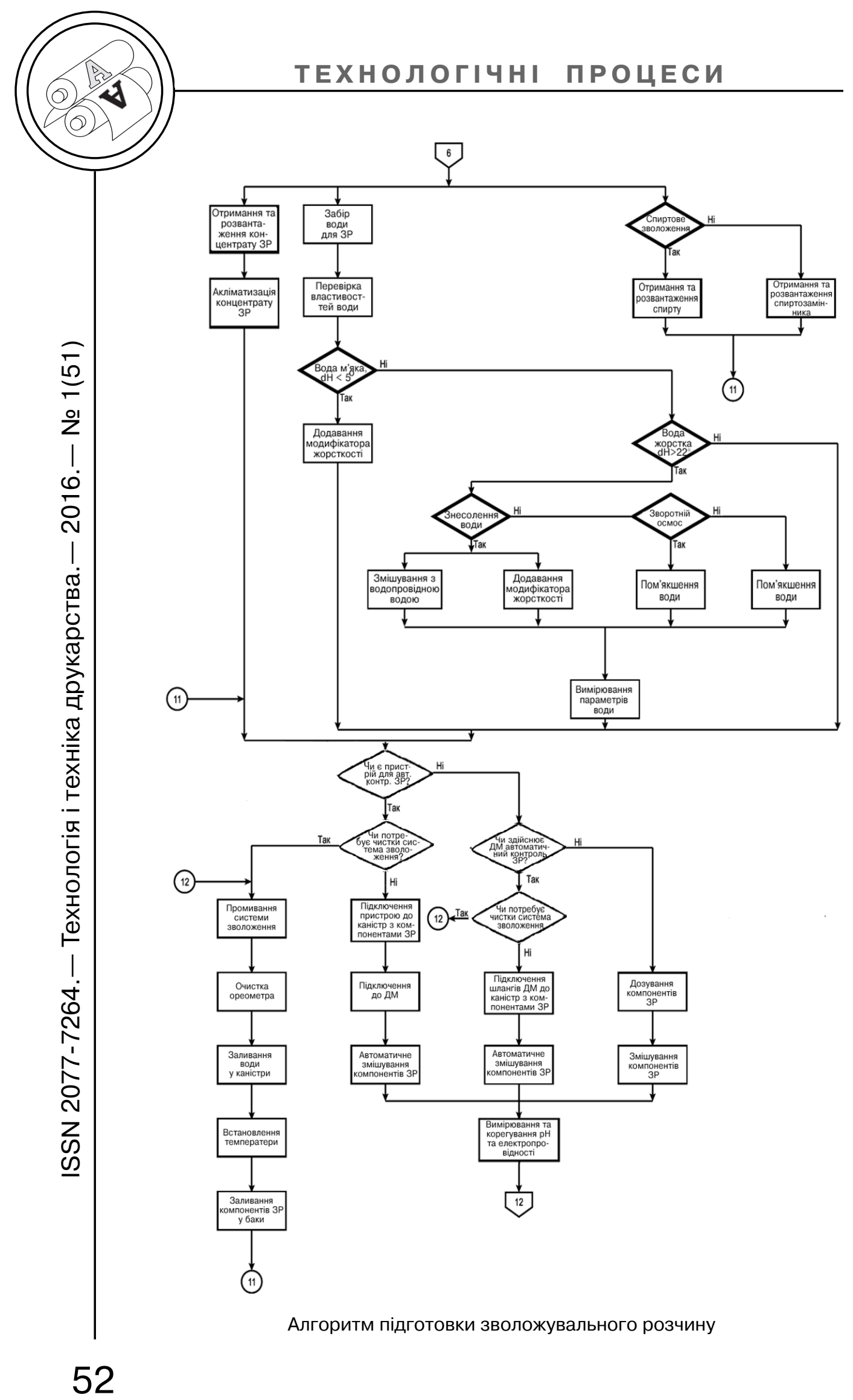


Виходячи зі сказаного вище можна назвати ряд переваг, що роблять плоский офсетний друк зі зволоженням одним 3 найбільш поширених:

- високий рівень автоматизації та комп'ютеризації. Сучасні поліграфічні комплекси за кордоном дозволяють зробити повністю автоматичним складування, постачання матеріалів на робочі ділянки, підготовку до друку, приведення, контроль та налаштування інших параметрів друку та відвантаження задрукованої стопи. Програмне забезпечення дозволяє вести замовлення на усіх стадіях виробничого циклу, здійснюючи попереднє налаштування обладнання та зберігаючи використані параметри налаштувань для наступних подібних замовлень;

- це напрямок, що розвивається тому, можна очікувати нових розробок, що зроблять технологічний процес, більш простим чи автоматизованим. Нові рішення на користь підвищення екологічності виробництва, виробничого клімату та ін.;

- офсетний друк має свій власний сегмент ринку, де він незамінний при поліграфічному виконанні (книжки, журнали, газети, буклети, листівки, документація суворої звітності та обліку та інше) та загалом має досить широку сферу застосування (крім вище названого, друк на полімерних матеріалах, тонких полімерних плівках, картонної та паперової упаковки);

- офсетний друк є найбільш вигідним та прибутковим у своєму сегменті. За даними 2012 року прибутковість бізнесу на основі плоского офсетного друку в 1,5 рази перевищує прибутковість цифрових способів друку PI [21];

- велика кількість постачальників та асортимент обладнання і матеріалів;

- добре відома технологія та, порівняно, велика кількість фахівців на ринку;

- web-to-print. Автоматизація додрукарської підготовки для великих тиражів. Нові можливості друку збірних тиражів;

- найвища якість друку та кольоровідтворення у своєму сегменті.

щодо ситуації на території України, то за останні 15 років використання упаковки зросло в 1,5 рази, а виробництво і споживання картону збільшилось більш ніж на $15 \%$. Загалом плоский офсетний спосіб друку зі зволоженням $є$ найбільш поширеним. Про це свідчать і кількість встановлених друкарських машин і частка матеріалів для офсетного друку на ринку $[2,3$, 8].

Увиразнюючи світові тенденції розвитку технологій поліграфічного обладнання для офсетного друку, можна окреслити такі основні позиції:

- глобальна комп'ютеризація та автоматизація виробничих процесів; продовження розробок у даному напрямку;

- розробка та впровадження рішень, щодо вдосконалення, автоматизації та комп'ютеризації старої та морально застарілої техніки;

- перехід до екологічно безпечних технологій та матеріалів, що регулюється державами в рамках «Ріо +20». 


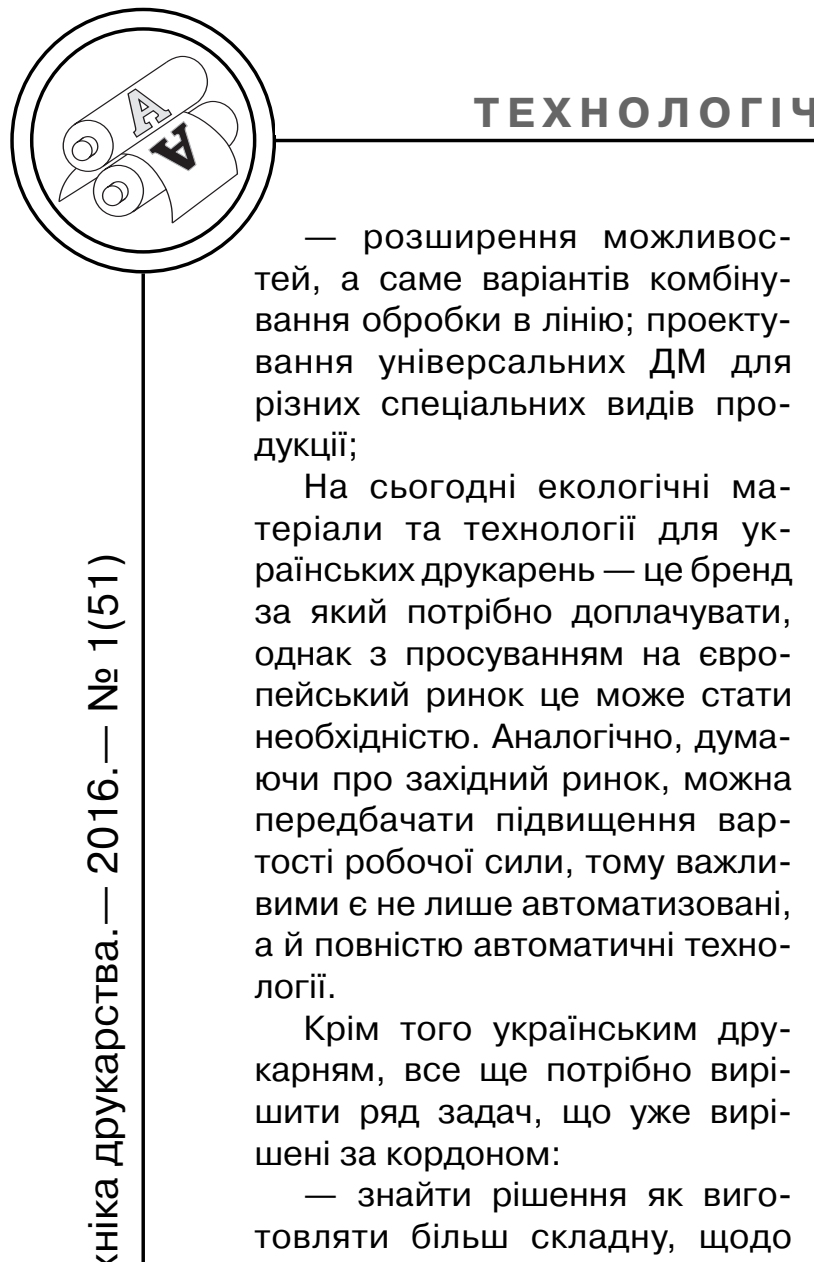

поліграфічного виконання, продукцію дешевшими способами;

- знайти компроміс між гнучкістю виробництва та спеціалізацією;

- визначити власну межу рентабельності, щодо малих тиражів та методи її зсуву до меншої позначки;

- знайти нові варіанти зниження вартості виробництва за умов подорожчання матеріалів.

\section{Висновки}

На основі аналітичного огляду визначено стан ринку поліграфічної продукції, насамперед, ринку упаковки.

Визначено рівень розвитку техніки та технологій офсетного друку. Узагальнено основні тенденції.

Визначено основні переваги офсетного способу друку.

\section{Список використаної літератури}

1. Величко О. М. Опрацювання інформаційного потоку взаємодією елементів друкарського контакту : монографія / О. М. Величко. - К. : Видавничо-поліграфічний центр «Київський університет», 2005. - 264 с.

2. Савченко К. І. Сучасний стан технологій друкування в Україні / К. І. Савченко, О. В. Зоренко, Т. В. Розум, О. М. Величко // Технологія і техніка друкарства. - 2011. - № 2(32). - С. 21-27. - Режим доступу : http://ttdruk.vpi.kpi.ua/article/view/52761.

3. Кривошей В. Якого кольору буває економіка? (у вимірах пакувальної індустрії) / В. Кривошей // Упаковка. - 2014. - № 5. - С. 14-20.

4. Золотухіна К. Друкарські фарби у поліграфії (сучасні тенденції) / К. Золотухіна // Упаковка. - 2013. - № 6. - С. 54-59.

5. Кушлик Б. Формні процеси плоского офсетного друку (сучасний стан) / Б. Кушлик // Упаковка. - 2013. - № 2. - С. 66-67.

6. Зоренко Я. В. Технології репродукування плоским офсетним друком : монографія / Я. В. Зоренко. ; за заг. ред. О. М. Величко. - К. : Видавничополіграфічний центр «Київський університет», 2015. - 176 с. - Режим доступу : http://orcid.org/0000-0001-5332-5296.

7. Скиба В. М. Технології основи тиражної стабільності друкарських форм : монографія / В. М. Скиба ; за заг. ред. О. М. Величко. - К. : ВПЦ «Київський університет», 2015. - 148 с.

8. Упаковка из картона в мире и Украине (состояние и тенденции развития) // Упаковка. - 2014. - № 3. - С. 53-55. 
9. Heidelberg медиабрифинг : «Добро пожаловать в будущее печати» // Курсив. - 2012. - № 6. - С. 10-15.

10. Heidelberg : новая философия производительности // Курсив. 2014. - № 3. - С. 14-19.

11. Конфигурации машин : занимаем нишу, догоняя Германию // Курсив. - 2012. - № 6. - С. 22-24.

12. Автоматизация газетной печати : все под контролем // Курсив. 2013. - № 1. - C. 14-16.

13. Upgrade без остановки или удобное «пианино» для печатника // Курсив. - 2014. - № 2. - С. 44-45.

14. Шариффулин M. Web-to-print : способы реализации [Електронний pecypc] // Publish. - 2015. - № 7-8. - Режим доступу : http://www.publish.ru/articles/201507-08_20013439.

15. Величко О. М. Новий технічний поступ технологій друкарства / О. М. Величко // Технологія і техніка друкарства. - 2008. - № 1(19). — C. $9-22$.

16. СТcP basysPrint : аналоговые пластины для офсета, лакировальные формы, сетки для трафарета, клише и другие области применения // Курсив. - 2013. - № 2. - С. 60-65.

17. H-UV Офсет нового поколения без «Исторических проблем» // Курсив. - 2013. - № 3. - С. 28-30.

18. ЭП-офсет : мгновенное закрепление краски // Курсив. - 2013. № 3. - C. 46-48.

19. Узкорулонка : одна за всех, или локомотив бизнеса // Курсив. 2012. - № 5. - С. 34-77.

20. Узкий рулон для широкой специализации или новый вариант развития типографий // Курсив. - 2011. - № 2. - С. 22-27.

21. Liderzy czy maruderzy? // PoliGrafika. - 2012. — \# 3. - P. 10-14.

\section{References}

1. Velychko O. M. Opratsiuvannia informatsiinoho potoku vzaiemodiieiu elementiv drukarskoho kontaktu : monohrafiia / O. M. Velychko. - K. : Vydavnycho-polihrafichnyi tsentr «Kyivskyi universytet», 2005. - 264 s.

2. Savchenko K. I. Suchasnyi stan tekhnolohii drukuvannia v Ukraini / K. I. Savchenko, O. V. Zorenko, T. V. Rozum, O. M. Velychko // Tekhnolohiia i tekhnika drukarstva. - 2011. - № 2(32). - S. 21-27. - Rezhym dostupu : http://ttdruk.vpi.kpi.ua/article/view/52761.

3. Kryvoshei V. Yakoho koloru buvaie ekonomika? (u vymirakh pakuvalnoi industrii) / V. Kryvoshei // Upakovka. - 2014. - № 5. - S. 14-20.

4. Zolotukhina K. Drukarski farby u polihrafii (suchasni tendentsii) / K. Zolotukhina // Upakovka. - 2013. - № 6. - S. 54-59.

5. Kushlyk B. Formni protsesy ploskoho ofsetnoho druku (suchasnyi stan) / B. Kushlyk // Upakovka. - 2013. - № 2. - S. 66-67.

6. Zorenko la. V. Tekhnolohii reprodukuvannia ploskym ofsetnym drukom : monohrafiia / la. V. Zorenko. ; za zah. red. O. M. Velychko. - K. : Vydavnychopolihrafichnyi tsentr «Kyivskyi universytet», 2015. - 176 s. - Rezhym dostupu : http://orcid.org/0000-0001-5332-5296.

7. Skyba V. M. Tekhnolohii osnovy tyrazhnoi stabilnosti drukarskykh form : monohrafiia / V. M. Skyba ; za zah. red. O. M. Velychko. - K. : VPTs «Kyivskyi universytet», 2015. - $148 \mathrm{~s}$.

8. Upakovka iz kartona v mire i Ukraine (sostojanie i tendencii razvitija) // Upakovka. - 2014. - № 3. - S. 53-55. 


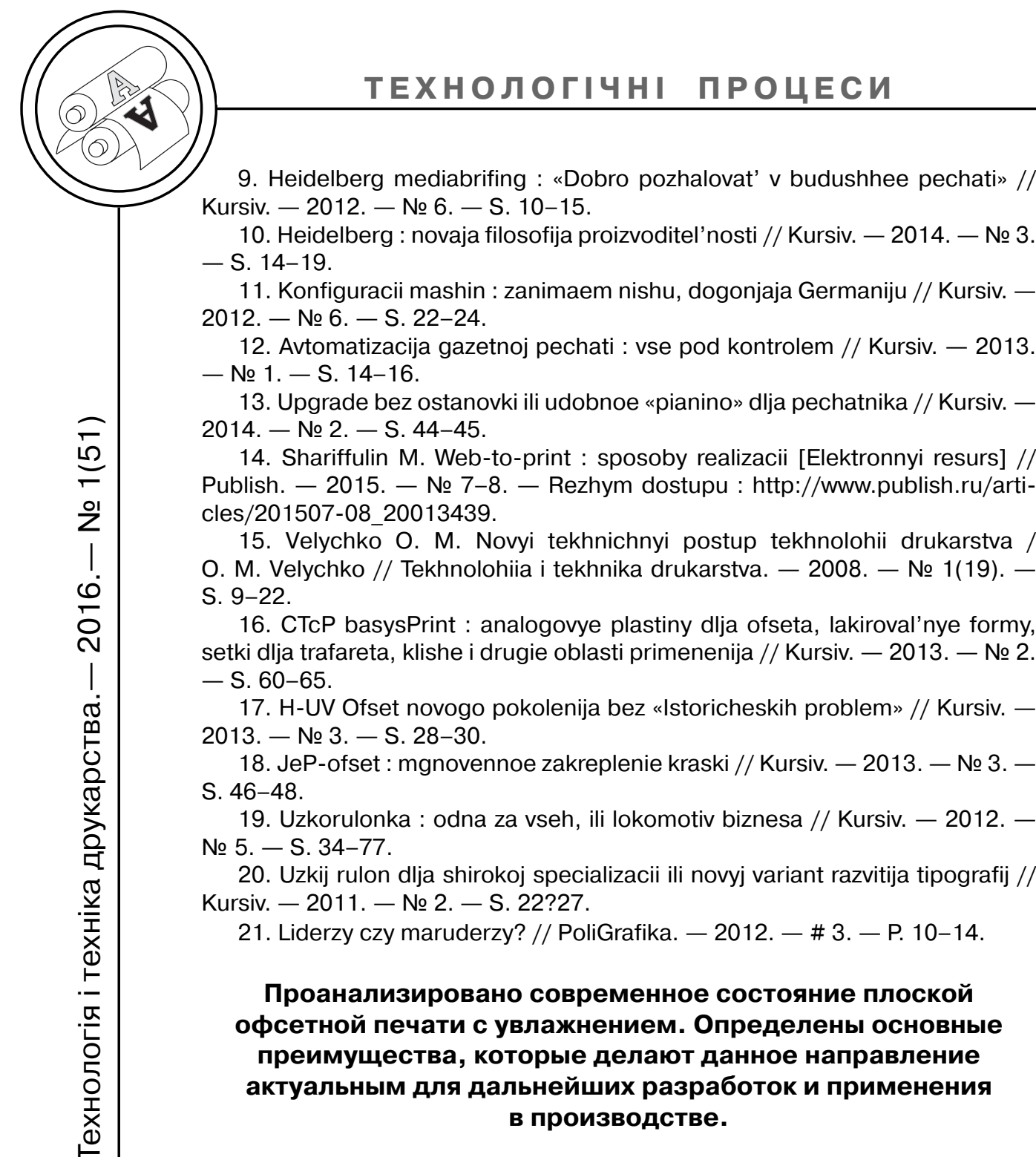

Ключевые слова: плоская офсетная печать с увлажнением; производство; полиграфическая продукция; рынок упаковки, современное состояние.

It was analyzed current state of offset printing and the main advantages that make this direction actual for future development and use in production.

\section{Keywords: flat offset printing with moistening; production; printing products; packaging market, the current state.}

